Research Article

\title{
Mapping BIM Uses for Risk Mitigation in International Construction Projects
}

\author{
Tsenguun Ganbat, ${ }^{1}$ Heap-Yih Chong $\mathbb{D}^{2},{ }^{2}$ and Pin-Chao Liao ${ }^{1}{ }^{1}$ \\ ${ }^{1}$ Department of Construction Management, School of Civil Engineering, Tsinghua University, Beijing 100084, China \\ ${ }^{2}$ Department of Construction Management, School of Built Environment, Curtin University, GPO Box U1987, Perth, \\ WA 6845, Australia
}

Correspondence should be addressed to Pin-Chao Liao; pinchao@tsinghua.edu.cn

Received 24 September 2019; Accepted 7 February 2020; Published 9 April 2020

Guest Editor: Binh Thai Pham

Copyright (c) 2020 Tsenguun Ganbat et al. This is an open access article distributed under the Creative Commons Attribution License, which permits unrestricted use, distribution, and reproduction in any medium, provided the original work is properly cited.

\begin{abstract}
International construction projects (ICPs) have become more popular in the current wave of globalization. The Building Information Model (BIM) has been adopted in ICPs. However, the utility of the BIM in ICPs for effective risk control remains unclear. This paper maps the relationship between ICP risks and BIM use to improve the adoption and selection of the BIM. The results show that the BIM can effectively facilitate communication management, mitigating risks engendered by language barriers among stakeholders, for instance, design errors. The BIM can also effectively mitigate risks caused by particular and temporal differences during the construction process. This research highlights internal/technical ICP risks that can be effectively mitigated by certain applications of the BIM; however, in contrast, external risks of ICPs cannot be mitigated by the BIM. However, some risks need to be addressed by new BIM functions. For example, regarding legal risks, laws and regulations of various countries can be included in the BIM information integration model to facilitate timely acquisition of legal provisions by project participants. This study complements prior risk-management research, which typically focused on the BIM as an advanced tool by which to manage project risk, such as design errors, quality, and budget. Practically, the contractor and owner can select suitable BIM applications for different project objectives and risks in the pre-project phase.
\end{abstract}

\section{Introduction}

The rapid adoption and development of the Building Information Model (BIM) has brought tremendous advantages to construction enterprises. However, new risks exist due to the characteristics of international construction, such as cross-cultural differences, multiple stakeholders, and legal and standards differences [1]. Although many BIMs have the capability to address complex construction problems, BIMs are still in the development stage, and new uses of BIMs are constantly emerging $[2,3]$. Previous studies have reviewed various applications of BIMs, from $4 \mathrm{D}$ scheduling aspects [4], 5D cost aspects [2,5], facility management [6], sustainability $[7,8]$, safety aspects [9], and general BIM tools for construction management [10]. These important studies provide useful references for end-users in selecting suitable
BIM applications for their projects. Most risk-management research based on BIMs focused on the BIM as an advanced tool by which to manage project risk, such as design errors, quality, budget, and visual perspective, but did not typically address ICPs' risk management explicitly [9]; however, most ICP risks related to proposed contract conflict and design error are caused by language differences. However, very little information is available as to select language barrier based from the perspective of ICP risks. Furthermore, reviews of BIM use in international construction risk management are few in number. Therefore, BIM cannot currently be effectively promoted and used in ICP management.

Hence, this study maps the relationship between ICP risk and BIM application to improve the adoption and selection of the BIM. The linkage between BIM application and ICP risks helps provide effective control or prevention of risks 
and thereby improve project performance. This study involved two main research tasks. First, a critical review was conducted to compile a list of ICP risks and BIM applications in construction projects. Subsequently, a panel discussion method was used to analyze the BIM applications in association with ICP risks. Second, a meta-network method was adopted to analyze which BIM applications would be of utility in ICPs to help achieve project objectives in terms of cost, time, quality, safety, and environment. This paper is organized into five sections. Section 1 explains the study's theoretical background. Section 2 describes the critical review and research design. Section 3 explains the results of the meta-network analysis. Section 4 discusses the study's research contributions. Section 5 summarizes the study's research findings, highlights its limitations, and presents suggestions for future studies.

In recent years, the risks associated with ICPs have gradually increased, due to the increased complexity and requirements of these projects. There is a wide range of risks associated with ICPs, such as structural risks, construction risks, health and safety risks, financial risks, and environmental risks. Risk management is critical to the success of any construction project. Several studies $[11,12]$ have shown that current risk management approaches largely depend on experience and multidisciplinary knowledge.

Moreover, there is a lack of interaction among types of risk information in current risk management approaches [9]. This may lead to information that is not effectively shared, recorded, and updated during the development of a project. Large amounts of risk information may be lost if they are not properly recorded and communicated to other project participants.

In recent years, information models have become increasingly popular. These models offer the potential for collaboration and communication, increased productivity and quality, and reduced project costs and implementation time [13]. Data-based collaboration and communication environments help identify and mitigate risks early $[14,15]$. BIMs have become a systematic approach and process that have changed the presentation of projects [16], design [17], and communication [18]. Many studies have proposed BIMs as a tool for managing project risks, involving design errors, occupational safety, quality, and budget, but they often do not directly reference the concept of risk management. Risk management will play a more important role as project participants begin to use these latest technologies as part of their daily work.

Since BIM technology can integrate information in an $\mathrm{nD}$ model [19], future BIM applications could process riskmanagement data [20]. In the construction industry, BIMs are continuing to develop; in practice, companies want to advance implementation theory and make full use of BIMbased tools to improve project performance and risk management [10]. However, in the current construction industry, the sharing and communication of risk information are often incomplete and inconsistent; it is necessary to integrate and visualize this information through BIMs. However, there is little BIM-related research that has focused on international construction project risk management.
Related studies of BIMs in international construction risk management have illustrated that the $4 \mathrm{D}$ system can visually simulate a proposed construction sequence, via which planners could easily identify potential risks [21]. Additionally, 3D visualization has been deployed to review and understand the degree and location of damaged components of a building when assessing potential hazards [22]. The 5D automated cost estimating model has been used to provide more accurate cash flow forecasts [23], and decision-making for workspace analysis [24]. However, these studies have yet to address ICP's critical risks, such as those related to language barriers, cultural barrier, and natural disaster. Furthermore, the studies to date only independently discussed BIM applications for specific risks; however, in construction projects, risks are often interrelated. Therefore, BIM applications should be considered holistically with respect to ICP risks.

\section{Materials and Methods}

The main research framework and research process of this study are shown in Figure 1. A detailed description of each step and method is provided below.

\subsection{Critical Review of ICP Risks and BIM Applications.} First, an in-depth literature review was conducted to determine the research trends in this field and the major research omissions, including the following aspects: (1) selecting classic literature on risk definition and risk management in ICPs; (2) assessing the development and application of BIMs in the construction industry, new BIM software, and other relevant literature to analyze international construction risk management and BIMs. Details of the ICP risks are shown in Table 1.

To compile the list of BIM applications in construction projects, more than one hundred peer-reviewed academic publications and twenty-five (25) BIM guidelines were selected and reviewed. PMBOK (2013) was also selected as a main reference. The details of BIM applications are shown in Table 2.

\subsection{Panel Discussion of BIM Applications from the Perspective} ofICP Risks. The panel discussion assessed BIM applications with respect to international construction risks. Twenty-four core project managers discussed a scenario simulation, based on grounded theory. This enabled generation of an international construction project risk-correlation matrix. This component of the study consisted of preliminary analysis, in-depth interviews, the establishment of an initial indicator set, and panel discussions of BIM application with respect to risk factors. The profile of the respondents is shown in Table 3.

The panel discussions commenced with an introduction of the discussion topic. The purpose of the discussions was to identify the role of BIM application in risk management of international engineering projects. Each panelist first assessed the identified BIM applications and verified 


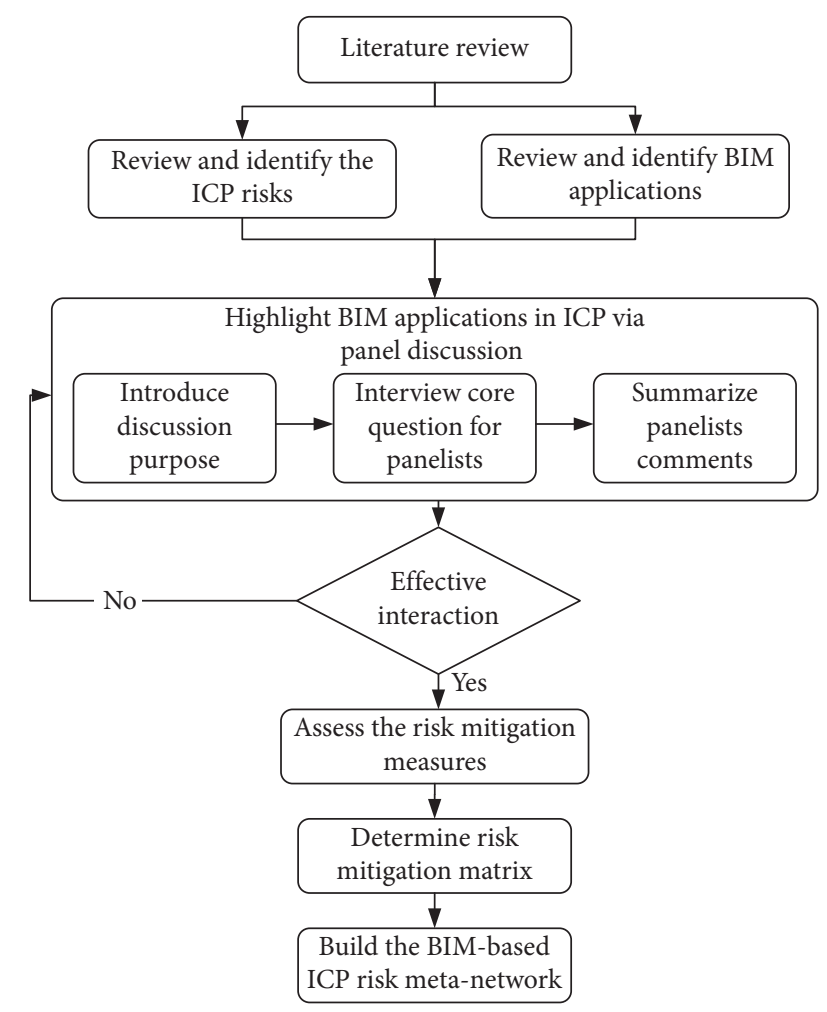

FIGURE 1: Research map.

whether the main uses of BIMs were represented. Second, the utility and benefits of these BIM applications were considered. Then, the particular role of these applications in risk management of international construction projects was discussed. Finally, the panelists' comments were summarized; panel discussion process is shown in Figure 2.

The project managers then evaluated the correlation between risks and BIM application, via a risk matrix. Respondents were asked to directly score the matrix according to the influence of BIM aspect $X$ on risk $Y$. The respondent was asked to consider all possible relationships and their directions. To quantify the relationships, respondents used a scale from 1 to 5 to represent the impact of the influence as well as the probability that this influence occurs [67]. If the respondent considered that there was no relationship between two risks, a value of 0 was assigned.

To obtain the degree of interaction between different risks and risk factors, a risk-structure matrix was used to evaluate the relationship between risks, risk impact on project objectives, and risk factors. To reflect the effect of the two directions, risk $\mathrm{A}$ on risk $\mathrm{B}$ and vice versa, but this needs to be stated explicitly for each type of bidirectional relationship, a numerical matrix corresponding to the two directions was aggregated, using geometric averages. The risk management intensity matrix was then obtained as $R_{i j}^{*}=\left(r_{i j}\right) n * n$, among $R_{j j}=\sqrt{R_{i j}^{e} \times R_{i j}^{c}}$. According to Yang and Zou's method of measuring the degree of association of each risk node, $R_{j}, S_{j}$ expressed the degree of association of each risk node $R_{j}$, which was equal to the sum of all the elements of the row vector in the risk matrix and all the elements of the vector in the risk column.

$$
S_{j}=\sum_{j=1}^{n} r_{i j}+\sum_{i=1}^{n} r_{i j}, \quad i=1,2, \ldots, n ; j=1,2, \ldots, n .
$$

Based on the panel discussion, the links between risks and BIM for risks were assessed. First, matrices for different network relationships were established, namely, the matrix representing the impact of risk on project objectives, that representing the interaction between risks, and that representing the impact of risk factors on risk. A total of 24 panelists' comments were collected from the on-site panel discussion with project managers.

2.3. Meta-Network Analysis. Finally, the assessment structures were inputted to a meta-network analysis tool (ORANetScences), to establish a network of risk interactions in the implementation phase of ICPs. From a network perspective, important risks and risk factors that influence project objectives were identified and analyzed.

Meta-network theory describes the commitment of resources, assignment, networks, and skills (PCANS), according to a model developed by Krackhardt and Carley [68]. These elements constitute a set of nodes, and relationships among these elements constitute a set of relationships. The meta-network provides a promising way by which to understand and visualize the complex interactions in a project's organizational network $[69,70]$. The metanetwork is multilayer, multilevel, and multimodal and can reveal the complex network systems in a project and identify the relationships between networks [69]. Recent network analysis approaches only address "who" is in the network, but the meta-network can simulate and analyze "who, when, where, what, and why" [69]. In a project's meta-network, changes in one network cascade into changes in other networks, thereby influencing the overall performance of the project [71].

The analysis was based on different types of nodes and links. In particular, there were four types of nodes: project objective (cost, time, quality, safety, and environment), 16 risk nodes (R1-R16, shown in Table 1), risk factors nodes (F1-F84, shown in Table 1), and 25 BIM application nodes (BC1-BC25, shown in Table 2). The types of networks among the different nodes were as follows: risk factor network (risks $\times$ factors), risk event network (risks $\times$ risks), risk mitigation network $(\mathrm{BIM} \times$ risks), and risk influence network (risks $\times$ objectives). The links in the different networks have different weights that reflect the degree of influence transfer. The purpose of this study was to determine the overall risk network of the project and changes in the overall risk network of the project given risk control measures, by understanding the relationships between different risk factors and the impact of different risk factors.

To reflect the overall effect of the two directions, the numerical matrix corresponding to the two directions was aggregated using a geometric average, and the risk-management intensity matrix obtained. The network connections in the meta-network were expressed by two directional influence matrices. All numerical matrices corresponded to the panel discussion results explained in Section 3.1. The 
TABLE 1: International construction project risks and risk factors.

\begin{tabular}{|c|c|c|c|}
\hline Code & Risks & Codes/risk factors & References \\
\hline R1 & $\begin{array}{l}\text { Wars and civil unrest among } \\
\text { local population }\end{array}$ & $\begin{array}{c}\text { F1 local political/social instability } \\
\text { F2 local government change } \\
\text { F3 cultural and religious conflicts } \\
\text { F4 exchange rate changes } \\
\text { F5 poor availability of local foreign exchange }\end{array}$ & $\begin{array}{l}\text { KarimiAzari et al. [25] } \\
\text { Zayed et al. [26] }\end{array}$ \\
\hline \multirow[t]{3}{*}{$\mathrm{R} 2$} & \multirow{3}{*}{$\begin{array}{l}\text { Increasing costs of fuel, material, } \\
\text { equipment, and labour }\end{array}$} & $\begin{array}{l}\text { F6 local currency changes } \\
\text { F7 local market price changes/inflation } \\
\text { F8 lack of funding }\end{array}$ & $\begin{array}{l}\text { Xiaopeng and } \\
\text { pheng [27] }\end{array}$ \\
\hline & & $\begin{array}{c}\text { F9 supply deficiencies (transport/delivery of materials, equipment, and } \\
\text { labour) }\end{array}$ & Liu et al. [28] \\
\hline & & F10 increase in bank interest rate & Zhao et al. [29] \\
\hline R3 & Exchange rate change & $\begin{array}{l}\text { F11 local and national tax increase (payment, evasion, implementation) } \\
\begin{array}{c}\text { F12 new local government regulations (taxation, labour, safety, waste, } \\
\text { environment, etc.) }\end{array}\end{array}$ & $\begin{array}{l}\text { Creedy et al. [30] } \\
\text { Santoso and } \\
\text { soeng [31] } \\
\text { Yildiz et al. [32] }\end{array}$ \\
\hline
\end{tabular}

F13 no fund management system

R4 Project fund shortage

F14 incorrect cash management/foreign exchange management F15 excess monetary investment in early project stages

F64 communication conflicts between project employees and residents Zayed et al. [26]; yildiz

(language barriers, use of translators, translation accuracy, etc.) et al. [32]

R5 The local public objected to the project

F65 malicious attacks on individuals by project employees

Dikmen and

F66 construction has considerable impact on residents' lives

Birgonul [33]

\begin{tabular}{c}
\hline F61 contracts with local governments are mandatory \\
F62 local government departments/services are inefficient, slow to \\
respond, and bureaucratic
\end{tabular}

Liu et al. [28]

Han et al. [34]

Hakami [35]

Tran and

molenaar [36]

F63 strict/different local business practices (business culture, systems, geography, personality, assimilation requirements, etc.)

Mathew et al. [37]

F80 construction pollution

F81 emission of hazardous chemicals and gases from construction

F82 improper disposal of construction waste

F83 hazardous construction sites and materials

F35 no substitute supplier/subcontractor in case of failure or failure to deliver

R7 Environmental damage caused by construction

F36 aboriginal land rights and owners

F37 restrictions of local laws and regulations (including customs/export/ import restrictions, etc.)

F38 poor land conditions (mining activities, public facilities, historic sites, pollutants, etc.)

F39 transport difficulties (poor local traffic conditions, traffic restrictions by relevant departments)

F40 local government interference

F41 imperfect supervision/control system (quality, cost, time)

F46 employees refused to sign up F47 employee diseases (plague

F48 project labour absence/potential occupational liability/laziness

F49 insufficient work experience of project employees in using materials/

R8 Regional disparity and climate impacts technologies/equipment (problems with the use of special materials and new materials)

F50 lack of safety knowledge, skills, and training for employees F51 poor accessibility of local materials/technologies/equipment (raw materials and semi-finished products are unavailable)

F52 improper material/technology/equipment procurement plan

F19 poor quality of goods and services from suppliers/subcontractors F41 imperfect supervision/control system (quality, cost, time)
Han et al. [34]

Xiaopeng and pheng [27]

Han et al. [34]

Xiaopeng and pheng [27]

Liu et al. [28]

Liu et al. [28] 
TABle 1: Continued.

\begin{tabular}{|c|c|c|c|}
\hline Code & Risks & Codes/risk factors & References \\
\hline R9 & $\begin{array}{l}\text { Quality defects in construction } \\
\text { materials }\end{array}$ & $\begin{array}{l}\text { F42 poor attitudes of field staff toward quality, cost, environment, safety, } \\
\text { trust, and opportunity } \\
\text { F43 lack of sampling inspection/product contamination leading to } \\
\text { quality defects } \\
\text { F44 low quality, competence, reliability, and productivity of project } \\
\text { employees } \\
\text { F45 insufficient identification of safety, quality, etc. } \\
\text { F30 insufficient technical resources, skills and knowledge of suppliers/ } \\
\text { subcontractors } \\
\text { F53 errors in installation of construction equipment }\end{array}$ & $\begin{array}{l}\text { El-sayegh and } \\
\text { mansour [38] } \\
\text { Zhao et al. [29] }\end{array}$ \\
\hline R10 & $\begin{array}{l}\text { Damage to labour, materials, } \\
\text { equipment, and building }\end{array}$ & $\begin{array}{c}\text { F54 equipment reliability/safety/low productivity } \\
\text { F55 local natural disasters (heatwave, wind, rain, cold, damp, fire, } \\
\text { tsunami, volcano, earthquake, flood, storm, tornado, landslide, } \\
\text { lightning, etc.) } \\
\text { F57 insufficient safety material and equipment } \\
\text { F58 low accessibility/high maintenance cost for key components and } \\
\text { accessories } \\
\text { F60 construction equipment type mismatch } \\
\text { F56 aboriginal land rights and owners } \\
\text { F67 local government approval/intervention } \\
\text { F68 government expropriation, government nationalization restrictions } \\
\text { on business operations } \\
\text { F69 the scale of the project does not conform to the scale required } \\
\text { F70 innovation and development needs (standardization level, } \\
\text { technology/details/materials, etc.) }\end{array}$ & $\begin{array}{c}\text { Hakami [35] } \\
\text { Liu et al. [28] } \\
\text { Santoso and soeng } \\
\text { [31] } \\
\text { Yildiz et al. [32] }\end{array}$ \\
\hline R11 & The design changes of the project & $\begin{array}{l}\text { F72 owners' overdependence on consultants/construction interventions } \\
\text { F74 design error } \\
\text { F75 imperfect databases, outdated information, late information, } \\
\text { inaccurate information, unusable information, incomprehensible } \\
\text { information } \\
\text { F76 design code conflicts with local code } \\
\text { F77 engineers' corruption/unreasonable decisions } \\
\text { F78 engineer's uncertainty about changes in the scope of work, } \\
\text { specifications, costs, duration, etc. } \\
\text { F39 transport difficulties (poor local traffic conditions, traffic restrictions } \\
\text { of relevant departments) } \\
\text { F42 poor attitudes of field staff toward quality, cost, environment, safety, } \\
\text { trust, and opportunity } \\
\text { F43 lack of sampling inspection/product contamination leading to } \\
\text { quality defects } \\
\text { F45 insufficient identification of safety, quality, etc. } \\
\text { F53 error in installation of construction equipment }\end{array}$ & $\begin{array}{l}\text { El-sayegh and } \\
\text { mansour [38] }\end{array}$ \\
\hline
\end{tabular}


TABle 1: Continued.

\begin{tabular}{|c|c|c|}
\hline Code & Risks & Codes/risk factors \\
\hline \multirow{15}{*}{$\mathrm{R} 12$} & \multirow{15}{*}{ Accident occurrence } & F54 equipment reliability/safety/low productivity \\
\hline & & $\begin{array}{c}\text { F55 local natural disasters (heatwave, wind, rain, cold, damp, fire, } \\
\text { tsunami, volcano, earthquake, flood, storm, tornado, landslide, } \\
\text { lightning, etc.) }\end{array}$ \\
\hline & & F56 insufficient safety education tips on project construction site \\
\hline & & F57 insufficient safety of material and equipment used \\
\hline & & $\begin{array}{l}\text { F58 low accessibility/high maintenance cost for key components and } \\
\text { accessories }\end{array}$ \\
\hline & & F59 crisis preparedness_-inadequate contingency planning \\
\hline & & F60 construction equipment type mismatch \\
\hline & & R9 quality defects in construction materials \\
\hline & & F16 lack of communication among project participants \\
\hline & & F17 unfair provisions in overseas contracts \\
\hline & & F18 conflict in industrial relations \\
\hline & & F19 poor quality of goods and services from suppliers/subcontractors \\
\hline & & $\begin{array}{c}\text { F20 supplier/subcontractor increased costs and delayed costs for goods } \\
\text { and services }\end{array}$ \\
\hline & & F21 supplier/subcontractor goods without warranty service \\
\hline & & F23 errors or omissions in quantities invoiced, inconsistent information \\
\hline \multirow{13}{*}{ R13 } & \multirow{13}{*}{$\begin{array}{l}\text { Contract disputes/termination } \\
\text { of contract }\end{array}$} & F24 project partner's credit insufficiency \\
\hline & & F25 owner's requirement for technology/rights is too stringent \\
\hline & & F26 issues with contract terms (date of completion is not clear, etc.) \\
\hline & & F27 lack of guarantee or insufficient guarantee \\
\hline & & F28 wrong expression of contract definition \\
\hline & & F29 claim management is unclear \\
\hline & & $\begin{array}{l}\text { F30 insufficient technical resources, skills and knowledge of suppliers/ } \\
\text { subcontractors }\end{array}$ \\
\hline & & F31 potential litigation issues; complexity of contracts and documents \\
\hline & & F33 owner's attitude towards scope, norm, cost, duration, etc. is not clear \\
\hline & & $\begin{array}{c}\text { F34 owners' requirements for environmental protection, safety, quality, } \\
\text { and time are too demanding }\end{array}$ \\
\hline & & $\begin{array}{c}\text { F35 no substitute supplier/subcontractor in case of failure or failure to } \\
\text { deliver }\end{array}$ \\
\hline & & F19 poor quality of goods and services from suppliers/subcontractors \\
\hline & & $\begin{array}{c}\text { F20 supplier/subcontractor increased costs and delayed costs for goods } \\
\text { and services }\end{array}$ \\
\hline
\end{tabular}

F24 project partner's credit insufficiency

Santoso and Soeng

Liu et al. [28]

\begin{tabular}{|c|c|c|c|}
\hline R14 & Subcontractor breach & $\begin{array}{l}\text { F26 issues with of contract terms (date of completion is not clear, etc.) } \\
\text { F28 wrong expression of contract definition } \\
\text { F30 insufficient technical resources, skills and knowledge of suppliers/ } \\
\text { subcontractors } \\
\text { F51 poor accessibility of local materials/technologies/equipment (raw } \\
\text { materials and semi-finished products are unavailable) } \\
\text { F22 owner's cash flow/arrears } \\
\text { F24 project partner's credit insufficiency } \\
\text { F26 issues with contract terms (date of completion is not clear, etc.) }\end{array}$ & \\
\hline R15 & Client defaults on project & $\begin{array}{l}\text { F28 wrong expression of contract definition } \\
\text { F31 potential litigation issues; complexity of contracts and documents } \\
\text { F33 owner's attitude towards scope, norm, cost, duration, etc. is not clear } \\
\text { F34 owners' requirements for environmental protection, safety, quality, } \\
\text { and time are too demanding }\end{array}$ & $\begin{array}{c}\text { Xiaopeng and pheng } \\
\text { [27] } \\
\text { Yildiz et al. [32] }\end{array}$ \\
\hline R16 & Disease and health problems & $\begin{array}{l}\text { F47 employee diseases (plague) } \\
\text { F84 unhygienic project site or staff dormitory, congenital diseases }\end{array}$ & $\begin{array}{l}\text { Yildiz et al. [32] } \\
\text { Thweatt and long [41] }\end{array}$ \\
\hline
\end{tabular}

Hanna et al. [40]

Creedy et al. [30]

Liu et al. [28]

Yildiz et al. [32]

Mathew et al. [37]
[31]

Yildiz et al. [32] 


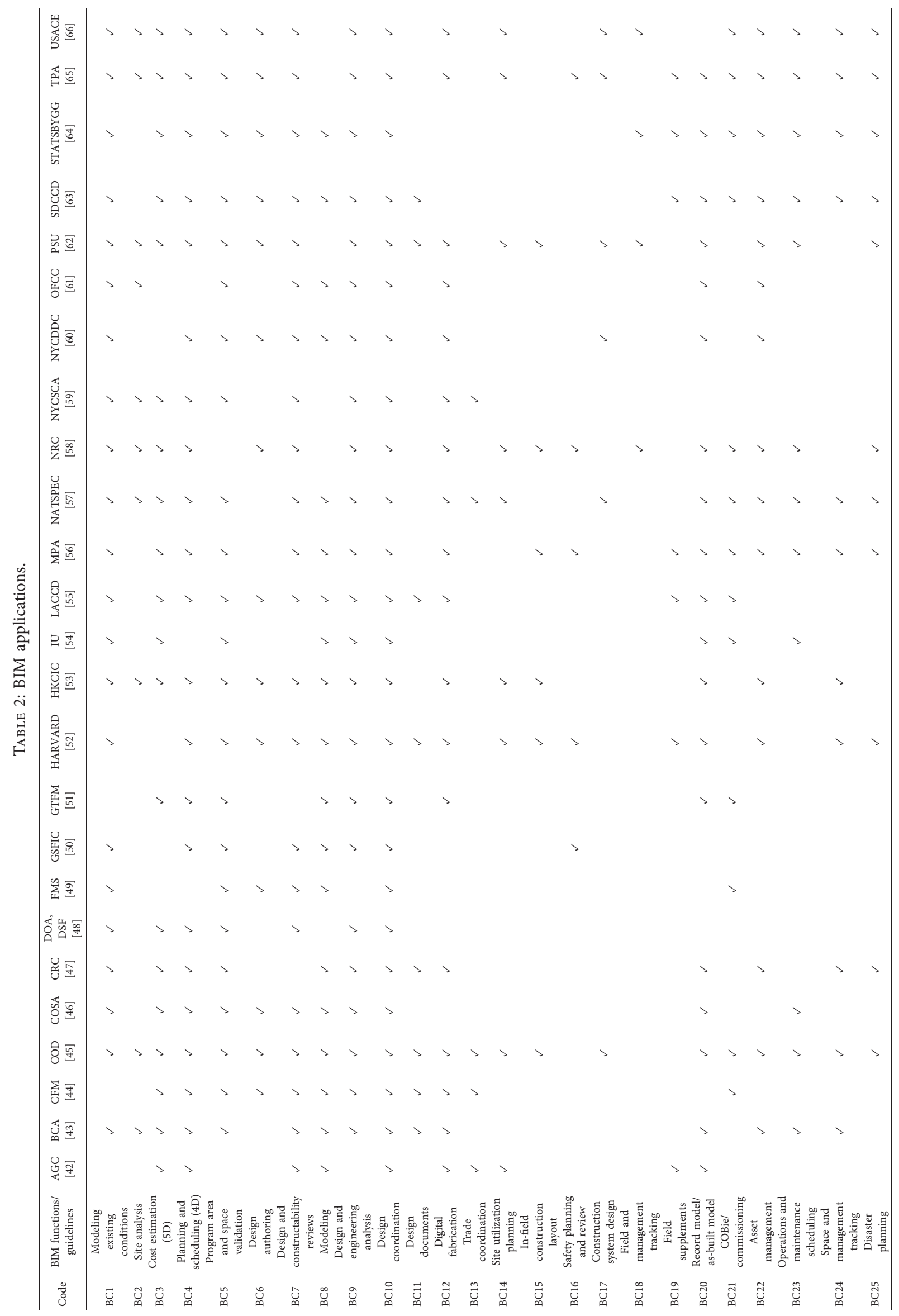


TABLE 3: Basic information of the participants.

\begin{tabular}{|c|c|c|}
\hline Characteristic & Category & Proportion of respondents (\%) \\
\hline \multirow{4}{*}{ Age (years) } & $\leq 25$ & $18(39 \%)$ \\
\hline & $26-30$ & $17(37 \%)$ \\
\hline & $31-35$ & $6(15 \%)$ \\
\hline & $\geq 36$ & $4(9 \%)$ \\
\hline \multirow{4}{*}{ Experience of international construction projects (years) } & $1-2$ & $27(60 \%)$ \\
\hline & $3-4$ & $12(27 \%)$ \\
\hline & $5-6$ & $5(10 \%)$ \\
\hline & $\geq 7$ & $1(3 \%)$ \\
\hline \multirow{4}{*}{ Education } & Bachelor's degree & $23(51 \%)$ \\
\hline & Master's degree & $10(22 \%)$ \\
\hline & High school degree and associates degree & $2(4 \%)$ \\
\hline & Other & $10(22 \%)$ \\
\hline \multirow{7}{*}{ Job position } & Administration office & $3(6 \%)$ \\
\hline & Materials and equipment department & $2(4 \%)$ \\
\hline & HSE management department & $2(4 \%)$ \\
\hline & Senior project leader (chief) & $3(6 \%)$ \\
\hline & Design department & $3(6 \%)$ \\
\hline & Contract department & $3(6 \%)$ \\
\hline & Engineering management department & $29(66 \%)$ \\
\hline
\end{tabular}

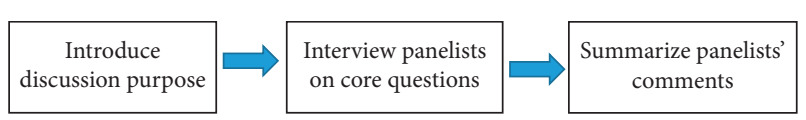

Figure 2: Panel discussion process.

outcome was a weighted graph $G=(N, K)$, where $N$ represents the total number of nodes (risks) and $K$ the total number of weighted links (relationships). The stakeholder category associated with each node is distinguished by color in the figures shown here. The thickness of each link represents its weight [72]. The meta-network analysis visualizes changes in the network, in network density, in the number of links (link count), and in the number of nodes.

\section{Results}

3.1. BIM Application to ICP Risk Meta-Network. Figure 3 shows the BIM-based ICP risk network, including the risk factor network (risks $\times$ factors), risk event network (risks $\times$ risks), risk mitigation network $(\mathrm{BIM} \times$ risks), and risk influence network (risks $\times$ objectives); the network statistics and network link count statistics are shown in Tables 4 and 5. The central network shows the most used BIM applications (green nodes). In the middle network, yellow nodes represent risk factors with a direct relationship between BIM types and risk factors. Also shown are the five project objectives, such as cost, time, quality, HS-health and safety, and E-environment. The whole circle of the network shows the risks, five project objectives, risk factors, and BIM uses.

The main BIM application that affects risk displayed in the meta-network center is $3 \mathrm{D}$ visualization and design. $3 \mathrm{D}$ visualization and design: after establishing a 3D design model with attribute information (e.g., for equipment, pipeline, civil engineering) permitting full collision inspection, 3D audit, and 3D check, a BIM can directly generate or extract 3D design drawings and bills of materials,

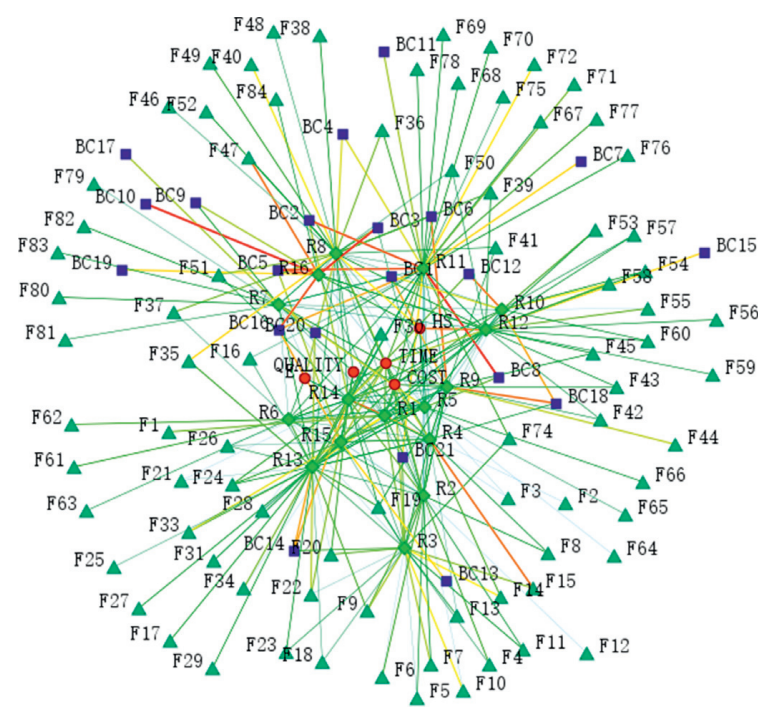

FIgURE 3: BIM-based ICP risk network.

TABLE 4: Network statistics.

\begin{tabular}{lcccc}
\hline Statistic & Minimum & Maximum & Average & $\begin{array}{c}\text { Standard } \\
\text { deviation }\end{array}$ \\
\hline Number of nodes & 1 & 128 & 8.385 & 8.537 \\
Number of links & 0 & 510 & 26.469 & 53.356 \\
Density & 0 & 0.14 & 0.887 & 0.268 \\
\hline
\end{tabular}

thereby preventing design errors, risk of material accounting errors, and so forth.

Effective communication with the owner: due to the language barriers associated with international engineering, the contractor and foreign owner often cannot communicate fully and effectively. Here, BIM technology may be used to integrate the professional design content into a visual $3 \mathrm{D}$ model. Regular review by the project manager and the owner will not only facilitate the owner's understanding of the real- 
TABle 5: Network link count statistics.

\begin{tabular}{lcccc}
\hline Network & Minimum & Maximum & Average & $\begin{array}{c}\text { Standard } \\
\text { deviation }\end{array}$ \\
\hline Risk $\times$ risk & 0 & 120 & 21.233 & 43.768 \\
Risk $\times$ factors & 1 & 45 & 4 & 7.203 \\
Risk $\times$ objectives & 4 & 44 & 23.714 & 13.292 \\
Risk & 1 & 33 & 4.184 & 5.185 \\
factors $\times$ BIM & & & & \\
\hline
\end{tabular}

time progress of the design but also facilitate communication and agreement between the owner and contractor in a visual environment, effectively reducing the amount of rework on-site (e.g., preventing design changes, communication disputes, engineering disputes, rework, etc.).

Simulation and optimization of construction scheme: in complicated projects, the difficulties and key points of the construction can be found in advance, and the construction scheme can be further optimized.

BIM visualization model and roaming use: textual technical content can be expressed in a visual model, so that construction personnel can more intuitively and deeply understand technical content. This may improve professional collaborative communication efficiency, avoid unnecessary material and labor waste, and reduce the workload associated with reading materials.

Construction progress auxiliary management: visual management of the advance schedule of the construction project can facilitate reasonable arrangement of construction procedures, installation progress, reduction of waste, and improving efficiency.

Composition and material control: statistical engineering, based on a 3D model and construction organization, can improve quota design, subproject quantity statistics, realtime multicount comparison, and facilitating cost control.

The model can obtain information on all materials, physical quantities, and quotas to release materials, thereby saving material usage and reducing costs. After the project is completed, the actual material usage and planned material usage will be automatically counted and analyzed, which provides a reliable reference when costing similar projects in future.

In the network analysis, the most influential BIM was the 5D model (Figure 4). The BIM 5D cost estimate is centrally located in the network and influences project costs and schedule targets, especially for project contract risks, security risks, and subcontractor risks. This information can be used to display virtual project builds for other stakeholders and thereby discover project-relevant information. Additionally, the model simplifies the concept of the project; misunderstandings among stakeholders are reduced because they can see the final design before the project starts. Any changes that occur during the build process, such architectural alterations, are automatically transferred to the model, and everyone can access the new information. The greatest benefit is that anyone involved in the project has access to

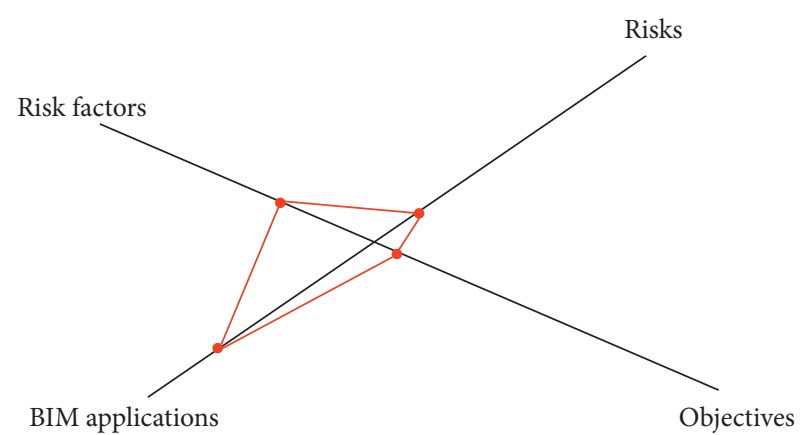

Figure 4: Node cross-analysis.

geometry, required resources, time, and cost, which enables all stakeholders to make quick decisions and reduces any misunderstandings that may occur.

The meta-network also can show the different networks relations. The direct relationships between the four metanetworks were demonstrated by node cross-analysis, shown in Figure 4. BIM types (in the network node named "Resources") have the most nodes and connections throughout the network, indicating that BIMs play a major role in the risk-management network. Moreover, of all relationships, that between BIM and risk factors was the strongest.

Figure 5 shows the network simulation result based on maximum likelihood estimation. Greater likelihood represents a greater chance that the event will occur under different conditions when the result is known. The results show that the central-hub assumptions in the network differed from other probability assumptions.

After applying BIMs, the density of the entire risk network was reduced by $69 \%$. The 5D BIM network contained 164 links, which reduced risk by approximately 56\%, with nodes reducing in number by $36 \%$ (reasonable cost planning, cost control). The 3D BIM network contained 232 links, which reduced risk by c. $23 \%$, with the number of nodes reducing by $25 \%$. The disaster plan network contained 251 links, reducing risk by c. 17\% (reduced risk of personnel safety accidents), and nodes by $19 \%$. The communication platform network contained 235 links, reducing risk by c. $22 \%$, and nodes by $23 \%$ by promoting early risk identification and risk communication.

The best potential risk management paths were identified by determining the shortest paths that could control links. For example, for the 5D BIM to COST, the shortest path length was 5 , and the number of shortest paths was 1 . For the path Owner's requirements unclear $($ F71) $\longrightarrow$ Technical and design changes $(\mathrm{R} 11) \longrightarrow$ Cost (6.16) affected value; in the initial contract, the owner's requirements are not clear or the owner does not document requirements, which will lead to technical and design changes during project implementation, which will increase workload and/or increase costs due to the need 


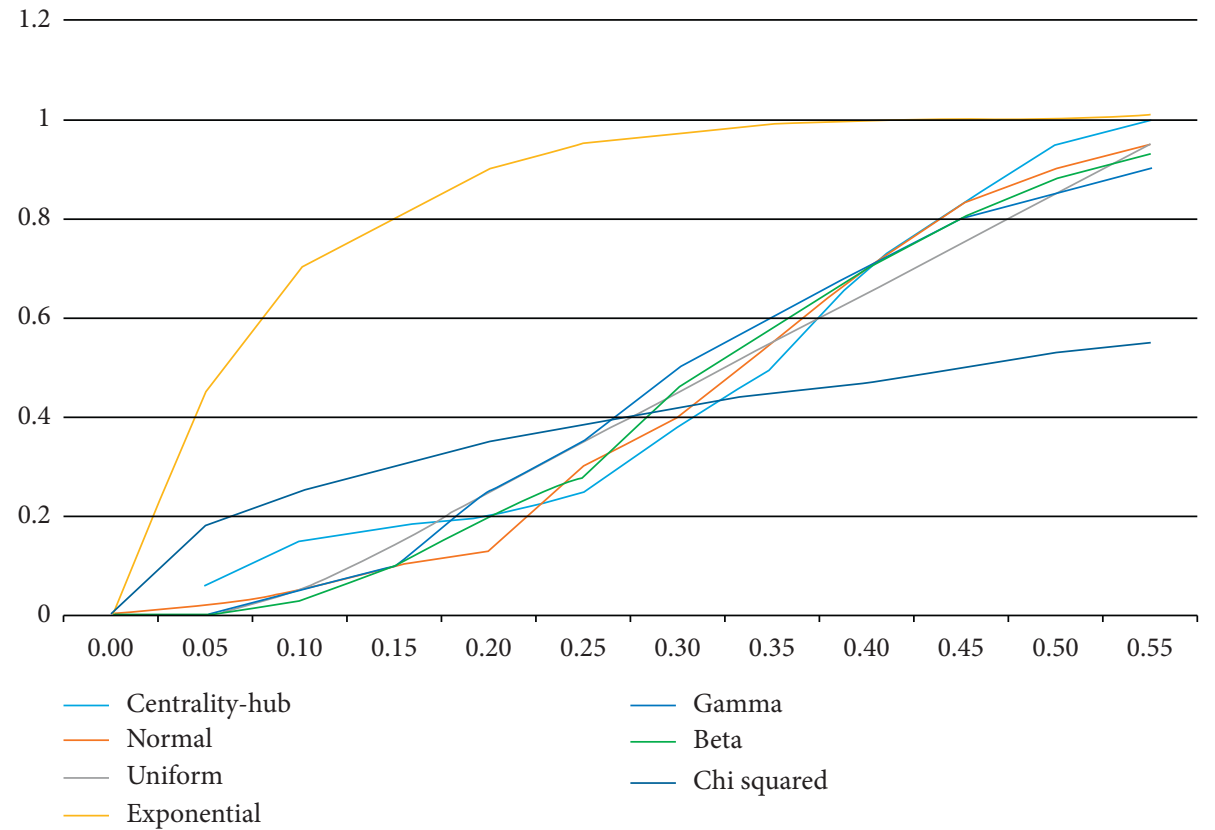

Figure 5: Network simulation results.

for new designs. The path Design errors (F74) $\longrightarrow$ Technology and design changes (R11) $\longrightarrow$ Cost (5.86) signifies that design errors are also a primary factor in design changes and continue to affect project costs.

\section{Discussion}

4.1. Theoretical Contribution. The meta-network revealed that BIMs can control internal risks and technical risks in ICPs, but they cannot control the external risks of ICPs. Political risk can be reduced by reviewing the country risk index (world political risk report). Social and cultural risks can be reduced by purchasing insurance (MIGA/AIG/ KLIN). Legal risks can be addressed by including the laws and regulations of various countries in the BIM information-integration model to facilitate the timely acquisition of relevant legal provisions. Economic risk can be addressed by including exchange rates between countries and interest rate changes in a 5D BIM at regular intervals; project financial managers or owners and contractors can regularly check the relevant information and adjust the project cost plan and construction plan according to economic changes. Health risk can be ameliorated using a safety management model to train staff on personal hygiene, and utilizing health screenings for timely detection of physical illness among staff. Environmental risk can be addressed via the platform or model of management of the environment to be developed, with its associated environmental management procedures and system management.

Advantages of BIMs have been studied thoroughly, and the rapidly available benefits contractors have obtained have been categorized in detail [73]. The process of facilitating BIM adoption and the latent challenges are being reciprocally studied $[74,75]$. In practice, enterprises need to advance implementation theories to fully use BIM-based tools and thereby improve project functionality [10]. While some features of BIMs can help address project risk, it is not possible to conduct comprehensive risk management.

Most risk-management research based on BIMs has focused on the BIM as an advanced tool by which to manage project risk, such as design errors, quality, and budget, from a visual perspective, but has rarely explicitly referenced ICP risk management [9]. Most ICP risks related to the proposed contract and design errors are caused by language differences; BIMs may help ameliorate the consequence of the risks.

4.2. Practical Implications. The practical implications of this research can be discussed from three perspectives, namely, shortage of talents, software issues, and government policy. From the perspective of the shortage of talents, the lack of individuals familiar with BIMs is the main problem underlying the application of BIM technology in enterprises. This includes a lack of professionals qualified to implement BIMs and a lack of systematic BIM technical training. BIM talent is the primary issue that needs to be addressed before BIM technology can be applied widely. Different national stakeholders have different perceptions and knowledge of BIMs. Therefore, it will take time for BIMs to be applied in ICPs.

Regarding technology issues, each country has developed different software, and compatibility and usability of packages differ. Therefore, before implementing a project, all parties should determine the software that will be used and the necessary standards. From an economic perspective, the benefits of deep application of BIM technology for enterprises are uncertain. The unclear long-term return on 
investment and high input costs have hindered the wide application of BIM technology.

From the perspective of government policy, there is currently no relevant BIM standard in the industry; each country has different BIM standards. Thus, legal liability discrepancies are unknown, which hinders the use of BIM software and the deep application of BIM technology. At present, the development of BIM technology needs further research and improvement, and potentially even changes in standards, processes, software, and policies because different owners and contractors have different understanding of BIM in different countries. As well as the aforementioned software compatibility issues, there exist difficulties in model management as data security differs among networks, as do network speeds; these issues incur the risk of data loss. The unclear legal liability associated with the BIM system, intellectual property issues, model ownership issues, and ownership of data mean that BIM has a high short-term cost. Further, many participants in international engineering projects attach great importance to their interests and image, and data input that intentionally conceals real data may occur, reducing data reliability.

Finally, the main practical contribution of this research is its suggestion of appropriate BIM applications to various stakeholders, contractors, and project owners, according to their own project objectives and major risks in the early stage of the project.

\section{Conclusion}

This study mapped the relationship between ICP risks and BIM applications. A BIM project risk-mitigation network was constructed. From the perspective of the ICP risk network, the BIM has a notable ability to prevent design errors and design change risks. BIM use has great potential to prevent risks, as evidenced by the risk network, which incorporated BIM architecture, management structure model, quality and safety management, site analysis, and collaborative management platform. BIMs can help users visualize risk information and understand the exact location of risk in the project, and help stakeholders understand risk and its impact on project duration. BIMs potentially eliminate the risks caused by language barriers in international engineering projects and improve risk communication and risk information management. BIMs can also eliminate time issues in information communication inherent to international engineering projects. By combining specific BIMs, stakeholders and contractors in different countries can view relevant content in real time and change incorrect or conflicting content in timely manner.

However, promoting the BIM use in international engineering projects presents some difficulties. From a technical point of view, the software developed in different countries lacks compatibility. Differences in data security levels and network speeds among networks pose a risk of data loss. In terms of management, difficulties may arise due to differences in professional models used among countries, owners, and contractors, who have different understandings of BIMs. Further, different BIM standards and BIM specifications will lead to information loss and affect cooperation. The legal liabilities associated with the BIM system are not clear concerning intellectual property rights, model ownership, data ownership, and so on. These problems should be addressed in the contract, to avoid later conflicts.

Certain limitations need to be considered when interpreting the research findings. First, the results of the risk assessment might only apply to Chinese international project contractors. Other types of projects or contractors in other countries may face different situations regarding risk management of ICPs. Nevertheless, the meta-network approach itself is generalizable and can be used in other similar risk management studies in different countries. Second, this study did not consider the role of BIMs in international project management from the perspective of BIM technology and software development. The study only assessed and interpreted the role of BIMs in ICP risk management from a management perspective. Future research is needed to combine management and technical aspects, which might require the design and development of related BIM software. Finally, the integrated management of the final risk mitigation strategy needs to be verified in an actual project.

\section{Data Availability}

The data used to support the findings of this study are available from the corresponding author upon request.

\section{Conflicts of Interest}

The authors declare that they have no financial and personal relationships with anyone or any entity whose interests could be positively or negatively influenced by the content of this paper.

\section{Acknowledgments}

The authors thank the Natural Science Foundation of China (no. 51878382) for their support of this study. The authors are also grateful for input received from the industry professionals who participated in this research.

\section{References}

[1] F. K. Adams, "Risk perception and Bayesian analysis of international construction contract risks: the case of payment delays in a developing economy," International Journal of Project Management, vol. 26, no. 2, pp. 138-148, 2008.

[2] M. A. Vigneault, C. Boton, H. Y. Chong, and B. CooperCooke, "An innovative framework of 5D BIM solutions for construction cost management: a systematic review," Archives of Computational Methods in Engineering, pp. 1-18, 2019.

[3] X. Wang and H.-Y. Chong, "Setting new trends of integrated Building Information Modelling (BIM) for construction industry," Construction Innovation, vol. 15, no. 1, pp. 2-6, 2015.

[4] R. Lopez, H.-Y. Chong, X. Wang, and J. Graham, "Technical review: analysis and appraisal of four-dimensional building information modeling usability in construction and engineering projects," Journal of Construction Engineering and Management, vol. 142, no. 5, Article ID 06015005, 2016. 
[5] Ž Turk, S. Wu, G. Wood, K. Ginige, and S. W. Jong, "A technical review of bim based cost estimating in UK quantity surveying practice, standards and tools," Journal of Information Technology in Construction, vol. 19, pp. 535-563, 2014.

[6] E. A. Pärn, D. J. Edwards, and M. C. P. Sing, "The building information modelling trajectory in facilities management: a review," Automation in Construction, vol. 75, pp. 45-55, 2017.

[7] H.-Y. Chong, C.-Y. Lee, and X. Wang, "A mixed review of the adoption of Building Information Modelling (BIM) for sustainability," Journal of Cleaner Production, vol. 142, pp. 4114-4126, 2017.

[8] J. K. W. Wong and J. Zhou, "Enhancing environmental sustainability over building life cycles through green BIM: a review," Automation in Construction, vol. 57, pp. 156-165, 2015.

[9] Y. Zou, A. Kiviniemi, and S. W. Jones, "A review of risk management through BIM and BIM-related technologies," Safety Science, vol. 97, pp. 88-98, 2017.

[10] T. Hartmann, H. van Meerveld, N. Vossebeld, and A. Adriaanse, "Aligning building information model tools and construction management methods," Automation in Construction, vol. 22, pp. 605-613, 2012.

[11] C.-S. Shim, K.-M. Lee, L. S. Kang, J. Hwang, and Y. Kim, "Three-dimensional information model-based bridge engineering in Korea," Structural Engineering International, vol. 22, no. 1, pp. 8-13, 2012.

[12] L. Zhang, X. Wu, M. J. Skibniewski, J. Zhong, and Y. Lu, "Bayesian-network-based safety risk analysis in construction projects," Reliability Engineering \& System Safety, vol. 131, pp. 29-39, 2014.

[13] S. Azhar, "Building information modeling (BIM): trends, benefits, risks, and challenges for the AEC industry," Leadership and Management in Engineering, vol. 11, no. 3, pp. 241-252, 2011.

[14] C. S. Dossick and G. Neff, "Messy talk and clean technology: communication, problem-solving and collaboration using building information modelling," Engineering Project Organization Journal, vol. 1, no. 2, pp. 83-93, 2011.

[15] A. Grilo and R. Jardim-Goncalves, "Value proposition on interoperability of BIM and collaborative working environments," Automation in Construction, vol. 19, no. 5, pp. 522530, 2010.

[16] A. Porwal and K. N. Hewage, "Building information modeling (BIM) partnering framework for public construction projects," Automation in Construction, vol. 31, pp. 204-214, 2013.

[17] W. Liu, H. Guo, H. Li, and Y. Li, "Using BIM to improve the design and construction of bridge projects: a case study of a long-span steel-box arch bridge project," International Journal of Advanced Robotic Systems, vol. 11, no. 8, p. 125, 2014.

[18] B. Hardin, BIM and Construction Management: Proven Tools, Methods, and Workflows, Wiley, Indianapolis, IN, USA, 2011.

[19] D. Migilinskas, V. Popov, V. Juocevicius, and L. Ustinovichius, "The benefits, obstacles and problems of practical bim implementation," Procedia Engineering, vol. 57, no. 1, pp. 767-774, 2013.

[20] N. H. Philipp, "Building information modeling (BIM) and the consultant: managing roles and risk in an evolving design and construction process," in Proceedings of Meetings on Acoustics Acoustical Society of America, San Francisco, CA, USA, December 2013.

[21] Y. Zhou, L. Ding, X. Wang, M. Truijens, and H. Luo, “Applicability of $4 \mathrm{D}$ modeling for resource allocation in mega liquefied natural gas plant construction," Automation in Construction, vol. 50, pp. 50-63, 2015.

[22] S. Amirebrahimi, A. Rajabifard, P. Mendis, and T. Ngo, "A framework for a microscale flood damage assessment and visualization for a building using BIM-GIS integration," International Journal of Digital Earth, vol. 9, no. 4, pp. 363386, 2016.

[23] Q. Lu, J. Won, and J. C. P. Cheng, "A financial decision making framework for construction projects based on 5D Building Information Modeling (BIM)," International Journal of Project Management, vol. 34, no. 1, pp. 3-21, 2016.

[24] H. Moon, H. Kim, C. Kim, and L. Kang, "Development of a schedule-workspace interference management system simultaneously considering the overlap level of parallel schedules and workspaces," Automation in Construction, vol. 39, pp. 93-105, 2014.

[25] A. KarimiAzari, N. Mousavi, S. F. Mousavi, and S. Hosseini, "Risk assessment model selection in construction industry," Expert Systems with Applications, vol. 38, no. 8, pp. 9105-9111, 2011.

[26] T. Zayed, M. Amer, and J. Pan, "Assessing risk and uncertainty inherent in Chinese highway projects using AHP," International Journal of Project Management, vol. 26, no. 4, pp. 408-419, 2008.

[27] D. Xiaopeng and L. S. Pheng, "Understanding the critical variables affecting the level of political risks in international construction projects," KSCE Journal of Civil Engineering, vol. 17, no. 5, pp. 895-907, 2013.

[28] J. Liu, X. Zhao, and P. Yan, "Risk paths in international construction projects: case study from Chinese contractors," Journal of Construction Engineering and Management, vol. 142, no. 6, Article ID 05016002, 2016.

[29] X. Zhao, B.-G. Hwang, and G. S. Yu, "Identifying the critical risks in underground rail international construction joint ventures: case study of Singapore," International Journal of Project Management, vol. 31, no. 4, pp. 554-566, 2013.

[30] G. D. Creedy, M. Skitmore, and J. K. W. Wong, "Evaluation of risk factors leading to cost overrun in delivery of highway construction projects," Journal of Construction Engineering and Management, vol. 136, no. 5, pp. 528-537, 2010.

[31] D. S. Santoso and S. Soeng, "Analyzing delays of road construction projects in Cambodia: causes and effects," Journal of Management in Engineering, vol. 32, no. 6, Article ID 05016020, 2016.

[32] A. E. Yildiz, I. Dikmen, M. T. Birgonul, K. Ercoskun, and S. Alten, "A knowledge-based risk mapping tool for cost estimation of international construction projects," Automation in Construction, vol. 43, pp. 144-155, 2014.

[33] I. Dikmen and M. T. Birgonul, "An analytic hierarchy process based model for risk and opportunity assessment of international construction projects," Canadian Journal of Civil Engineering, vol. 33, no. 1, pp. 58-68, 2006.

[34] S. H. Han, J. E. Diekmann, Y. Lee, and J. H. Ock, "Multicriteria financial portfolio risk management for international projects," Journal of Construction Engineering and Management, vol. 130, no. 3, pp. 346-356, 2004.

[35] W. G. M. Hakami, "The critical factors of project life cycle in Sudanese construction projects," International Journal of Engineering Sciences \& Research Technology, vol. 4, no. 3, pp. 518-532, 2015.

[36] D. Q. Tran and K. R. Molenaar, "Impact of risk on designbuild selection for highway design and construction projects," Journal of Management in Engineering, vol. 30, no. 2, pp. 153-162, 2014. 
[37] S. Mathew, D. Tran, and L. D. Nguyen, "Examining impact of risk on cost growth in design-build projects using structural equation modeling," in Proceedings of the Construction Research Congress 2018: Construction Project Management-Selected Papers from the Construction Research Congress 2018, American Society of Civil Engineers, Reston, VA, USA, pp. 659-669, April 2018.

[38] S. M. El-Sayegh and M. H. Mansour, "Risk assessment and allocation in highway construction projects in the UAE," Journal of Management in Engineering, vol. 31, no. 6, Article ID 04015004, 2015.

[39] J. K. Lee, S. H. Han, W. Jang, and W. Jung, “"Win-win strategy" for sustainable relationship between general contractors and subcontractors in international construction projects," KSCE Journal of Civil Engineering, vol. 22, no. 2, pp. 428-439, 2018.

[40] A. S. Hanna, K. Blasier, and D. G. Aoun, "Risk misallocation on highway construction projects," Journal of Legal Affairs and Dispute Resolution in Engineering and Construction, vol. 7, no. 4, Article ID 04515002, 2015.

[41] W. T. Thweatt and R. J. Long, "EPC contract risk analysis associated with onshore projects in developing countries," Long International, vol. 303, pp. 1-31, 2017.

[42] AGC, The Contractor's Guide to BIM, Associated General Contractors of America, Richmond, VA, USA, 2009.

[43] BCA, Singapore BIM Guide, Building and Construction Authority, Singapore, 2013.

[44] CFM, The VA BIM Guide, Department of veterans affairs. Construction \& Facilities Management, Washington, DC, USA, 2010.

[45] COD, BIM Guide, College of the Desert, Palm Desert, CA, USA, 2011.

[46] COSA, Building Information Modeling (BIM) Development Criteria and Standards for Design \& Construction Projects, COSA BIM Standards, San Antonio, TX, USA, 2011.

[47] CRC, National Guidelines for Digital Modeling, CRC for Construction Innovation, Brisbane, Australia, 2009.

[48] D. S. F. DOA, BIM Guidelines \& Standards for Architects and Engineers, Department of Administration. Division of State Facilities, Madison, WI, USA, 2012.

[49] FMS, BIM Guidelines, University of Southern California Facilities Management Services, Los Angeles, CA, USA, 2012.

[50] GSFIC, BIM Guide. Georgia State Financing and Investment Commission, GSFIC, Tbilisi, GA, USA, 2013.

[51] GTFM, Georgia Tech BIM Requirements \& Guidelines for Architects. Engineers and Contractors, Georgia Tech Facilities Management, GTFM, Tbilisi, GA, USA, 2016.

[52] Adriaanse, BIM Uses Guide, Harvard University Construction Management Council, Cambridge, UK, 2016.

[53] HKCIC, CIC Building Information Modelling Standards (Phase One), Construction Industry Council, Wanchai, China, 2015.

[54] IU, BIM Guidelines \& Standards for Architects, Engineers, and Contractors, Indiana University, Indianapolis, IN, USA, 2015.

[55] LACCD, BIM Standard, Los Angeles Community College District, , Los Angeles, CA, USA, 2016.

[56] MPA, Appendix A: MPA BIM Guidelines, Massachusetts Port Authority, Boston, MA, USA, 2015.

[57] NATSPEC, NATSPEC National BIM Guide, NATSPEC Construction Information, Sydney, Australia, 2016.

[58] NRC, National BIM Guidelines and Case Studies for Infrastructure, Sustainable Built Environment National Research Centre, Perth, Australia, 2014.
[59] NYCSCA, BIM Guidelines and Standards for Architects and Engineers, New York City School Construction Authority, New York, NY, USA, 2014.

[60] NYCDDC, BIM Guidelines, Department Design and Construction, New York, NY, USA, 2012.

[61] OFCC, BIM Protocol, State of Ohio Facilities Construction Commission, Columbus, OH, USA, 2012.

[62] PSU, BIM Execution Planing: BIM Uses, Penn State University, University Park, Harrisburg, PA, USA, 2011.

[63] SDCCD, BIM Standards for Architects, Engineers \& Contractors, San Diego Community College District, San Diego, CA, USA, 2012.

[64] Statsbygg, Statsbygg BIM Manual, Statsbygg, Oslo, Norway, 2013.

[65] TPA, "E/A design division BIM standard," The Port Authority of NY \& NJ Engineering Department, New York, NY, USA, 2016.

[66] USACE, Roadmap for Life-Cycle BIM, United States Army Corps of Engineers, Washington, DC, USA, 2012.

[67] Y. Li and X. Wang, "Risk assessment for public-private partnership projects: using a fuzzy analytic hierarchical process method and expert opinion in China," Journal of Risk Research, vol. 21, no. 8, pp. 952-973, 2016.

[68] D. Krackhardt and K. M. Carley, "PCANS model of structure in organizations," Research report series/Carnegie Mellon University Institute for Complex Engineered Systems, Carnegie Mellon University, Pittsburgh, PA, USA, 1998.

[69] K. Carley, J. Diesner, J. Reminga, and M. Tsvetovat, “Toward an interoperable dynamic network analysis toolkit," Decision Support Systems, vol. 43, no. 4, pp. 1324-1347, 2007.

[70] J. Zhu and A. Mostafavi, "Dynamic meta-network modeling for an integrated project performance assessment under uncertainty," in Proceedings of the Construction Research Congress 2016, pp. 2340-2350, San Juan, Puerto Rico, MayJune 2016.

[71] K. Carley, P. Pattison, and R. L. Breiger, Dynamic Social Network Modeling and Analysis: Workshop Summary and Papers, National Academic Press, Washington, DC, USA, 2003.

[72] R. J. Yang and P. X. W. Zou, "Stakeholder-associated risks and their interactions in complex green building projects: A social network model," Building and Environment, vol. 53, pp. 208-222, 2014.

[73] L. L. Foster, "Legal issues and risks associated with building information modeling technology," University of Kansas, Lawrence, Kansas, Doctoral dissertation, 2008.

[74] N. Gu and K. London, "Understanding and facilitating BIM adoption in the AEC industry," Automation in Construction, vol. 19, no. 8, pp. 988-999, 2010.

[75] F. Khosrowshahi and Y. Arayici, "Roadmap for implementation of BIM in the UK construction industry," Engineering, Construction and Architectural Management, vol. 19, no. 6, pp. 610-635, 2012. 